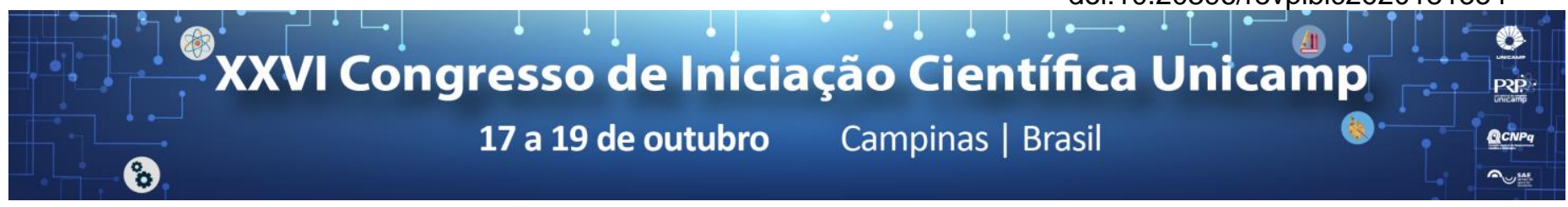

\title{
O Debate entre Noam Chomsky e Michel Foucault
}

\author{
Eduardo Barros Mariutti, Vinícius Domeniconi Bittencourt*
}

\section{Resumo}

Este projeto de Iniciação Científica propõe uma revisão de literatura que orbita o debate entre o cientista cognitivo e pai da Linguística moderna, Noam Chomsky, e o filósofo e historiador das ideias, Michel Foucault. O foco é perscrutar o tema criatividade de acordo com o sistemas de pensamento muito bem definido de cada autor. $O$ debate é polêmico pois reflete uma tensão que se envidencia entre os conhecimentos que se propõe absolutos, isto é, para além do tempo, como o modelo de cognição e aquisição de linguagem desenvolvido por Chomsky com a Gramática Gerativa e a análise histórica, precisamente desenvolvida através da arqueologia como procedimento, de Foucault.

\section{Palavras-chave: \\ Foucault, Chomsky, criatividade.}

\section{Introdução}

O título da discussão "Debate sobre a Natureza Humana" pode dar uma falsa noção de que ambos os autores possuem concepções de uma "Natureza Humana". Apenas Noam Chomsky adota e elabora esse conceito. Com inúmeras influências do lluminismo e do Romantismo dos séculos XVIII e XIX que vão de Descartes, Humboldt e Peirce a Karl Marx e Bakunin, ele desenvolve esse conceito com o fim de fundamentar sua teoria linguística. Com relação a Foucault, neste momento de sua reflexão categorizada como arqueologia do saber, sua forma de pensar tenta sempre enquadrar os discursos e conceitos nas suas devidas epistemes, isto é o conjunto de saberes válidos em uma época. Deste modo ele é cético quanto à concepção de uma "Natureza Humana", principalmente quando diz respeito à contribuição do homem como agente e ser criativo.

\section{Resultados e Discussão}

A Linguística, na concepção de Chomsky, é uma ciência natural e objetiva que qualifica a Linguagem como um sistema de base biológica que descende de um único indivíduo. Para ele todos os seres humanos nascem com um esquematismo inato, "duro" - caso contrário, se fôssemos suficientemente plásticos, ele argumenta, seríamos moldados pelo ambiente - - que nos permite perceber inconscientemente regras linguísticas e nos possibilita falar qualquer língua. Assim, concatenamos uma série de dados multifacetados que percebemos através de módulos mentais que interpretam a visão e a audição organizando-os simbolicamente de modo que, na sua significação, expressam-se altamente articulados. Isto promove o conceito de criatividade para Chomsky: algo trivial e idiossincrático que permite que cada pessoa entenda e organize seu universo simbólico de maneira própria. Além disso, um sistema de regras bem definido permite, segundo ele, tanto uma especificação do que é um arcabouço de uma teoria científica possível, quanto um esboço para liberdade e outras características humanas fundamentais como a justiça. Para Foucault, no seu primeiro livro de peso, A História da Loucura na Idade Clássica, ele descreve a emergência de uma noção de humanismo assentada na recuperação da Razão clássica e dos direitos civis que, segundo Artaud, é mais uma redução do homem do que um engrandecimento porque se concretiza como uma prática excludente. Nessa obra Foucault analisa a "história do Outro", agora, na sua segunda obra de peso, As palavras e as coisas, cujo recorte histórico faz eco ao projeto da primeira, ele escreverá a "história do Mesmo". Baseado na ideia de episteme, isto é, o "espaço de dispersão" e um "campo aberto de relação" que forma seus próprios objetos, sujeitos e conteúdos (Cantioto), ele se perguntará quais são os a priori históricos que permitem a existência de discursos surgirem e se sobreporem a saberes existentes, obliterando-os. Na época em que ele estava escrevendo, ele dialogava com o historiador Paul Veyne, nutrindo-se principalmente da ideia de "regimes de verdade" e "efeitos de verdade" (naturalização), pois a verdade não é um acúmulo de conhecimentos em uma progressão linear, isso é o que ele chamaria de "efeito de superfície" devido à disruptura profunda das epistémes (entre Renascimento e Idade Clássica, entre Idade Clássica e a Modernidade. Foucault alerta no debate que a concepção de "Natureza Humana" que, é simultaneamente ideal e real, é definida a partir de termos que emprestamos da nossa própria sociedade, civilização e cultura que são muito particulares, ocidentais forjados não só por regras linguísticas, mas epistemológicas, uma gramática política. Ele exemplifica isso com a concepção de natureza humana marxista da virada do século XIX e XX cuja noção de sexualidade, família, estética eram burguesa. Procurando fugir de definições marxistas, existencialistas, estruturalistas, identifica a emergência do homem nos domínios que o enfocam como ser vivente, trabalhador e falante eximindo a contribuição individual, criativa, de agência porque esta, segundo seu arcabouço teórico, está subordinada aos quadros de saber-poder.

\section{Conclusões}

A emergência das Ciências Humanas e, sobretudo, do olhar positivo sobre o ser humano implica coloca-lo em uma dobradiça ambígua ora filosófica, ora científica; ora objeto da pesquisa, ora sujeito pesquisador que se encontra em uma episteme específica, localizada, hegemônica e que se propõe global. 